\title{
Knowledge and attitude of Sudanese school health teachers regarding first aid management of dental trauma
}

\author{
Nissreen N. Mergany ${ }^{1}$ YahiaE. Ibrahim² and Amal H. Abuaffan ${ }^{3 *}$ \\ ${ }^{1}$ Department of Orthodontics, Pedodontics and Preventive Dentistry, Faculty of Dentistry, University of Khartoum, Sudan \\ ${ }^{2}$ Department of Conservative, Faculty of Dentistry, University of Khartoum, Sudan \\ ${ }^{3}$ Head Department of Orthodontics, Pedodontics and Preventive Dentistry, Faculty of Dentistry, University of Khartoum, Sudan
}

\begin{abstract}
Background: School teachers can play an essential role in managing traumatic dental injuries (TDIs). International studies reveal that basic school personnel have little knowledge about emergency dental care and management. The aim of this study isto assess the level of knowledge and attitude of Sudanese school health teachers in Khartoum state regarding first aid management of dental trauma.
\end{abstract}

Methods: A cross sectional study of self-administered questionnaire consists of; demographic data, self-assessment, knowledge and attitude, was filled by 195 school health teachers. Data were analyzed using t-test, one-way ANOVA and Pearson correlation coefficient.

Results: Entirely inadequate knowledge regarding the management of tooth fracture and avulsion was observed and $92.3 \%$ of the participants scored $<10$ points. Most participants (90.3\%) were unsatisfied with their awareness and suggested further education on the topic should be offered. No statistical significant difference between knowledge and demographic variations $(P>0.05)$. Whereas, significantwas found between attitude and first aid training $(\mathrm{p}<0.05)$.

Conclusion: The present results revealed considerably squat knowledge of the school health teachers regarding the first-aid management of dental trauma. Most of the participant have positive attitude toward management of the traumatic dental injuries.

\section{Introduction}

Traumatic dental injury (TDI) is a public dental health problem due to its frequency, occurrence at young age, cost and treatment may continue for the rest of the patient's life. Statistics from many countries show that one third of preschool children suffered a TDI involving the primary dentition while one fourth of the permanent dentition and variations have been observed between and within countries[1]. 71- $92 \%$ of all TDIs sustained in a lifetime occur before the age of 19 years[2].Traumatic dental injuries appear to affect schoolchildren's oral health related quality of life (OHRQoL)[3].

Traumatic dental injury with unmet treatment need is associated with reduced OHRQoL; adolescents affected by TDI with unmet treatment need are at greater risk of suffering impacts on OHRQoL in the form of Oral Impact on Daily Performance OIDP compared to those with no history of TDI[4].Complicated TDIs have a negative impact on the OHRQoL of preschool children and their parents[5].

It well documented that TDIs occur at home, followed by school and other public places[2].The prognosis of traumatized teeth depends on the correct measures taken immediately after injury, which often relies on lay people such as the children's parents and their school teachers who were present at the site of accident, prior to the initial dental contact[6].

In Sudan few studies investigated the prevalence of TDIs. In 1981, Baghdady et al reported 5.1\% prevalence of traumatized anterior teeth in 3507 primary school children [7]. Recently, in 2015 the prevalence had been reported by Shahar and Abuaffana little more 9.1\% among 9-12 years old Sudanese children and boys experienced more injury than girls 1:2.2 and more commonly enamel fracture[8].

In Khartoum, capital of Sudan each public primary school (governmental) has one school health teacher, responsible for humanizing the school health environment, providing emergency management, screening of new cases of vitamin A deficiency and increasing the awareness of school children with regard to different health issues, through daily messages at the queue.

In Sudan, school health teachers can play an essential role in promoting self-care for children who sustain dental injuries. Therefore, this study intended to evaluate the knowledge and attitude of Sudanese school health teachers regarding first aid management of dental trauma

\section{Material and methods}

A list of all governmental primary schools was obtained from the authorities in the two localities of the Khartoum state, and for each locality the desired sample size obtained through simple random technique. During the survey, some teachers were not found at schools either due to illness or study leave, so the nearest schools were selected. The calculated sample size was found to be 207 school health teachers.

Correspondence to: Amal H. Abuaffan, Associate professor and head department of Orthodontics, Pedodontics and Preventive Dentistry, Faculty of Dentistry, University of Khartoum, Sudan, Tel: 00249-912696035; 00249-927202131; E-mail: amalabuaffan@yahoo.com

Key words: School health teacher, dental trauma, first aids

Received: March 02, 2016; Accepted: March 31, 2016; Published: April 12, 2016 
Structured self-administered questionnaire had been adopted and modified from previous studies [9-11]. The questionnaire constructed in English so, it had been translated to Arabic and back to English for validation.

The questionnaire consists of four parts. Part 1, questions on personal and professional profile of the respondents, while part II considers self assessed knowledge with regard to public education programs on dental trauma emergency management, the third part of consists of questions on the immediate management of two scenarios of dental injuries; the first case is a fractured tooth in a 9-year girl; the second is a case of avulsion in a 12-years boy. Part IV includes variables describing the teacher's attitude using 5-Point Likert Scale.

The reliability of the survey instrument was determined by Cronbach's alpha [12] as 0.655 and 0.693 for attitude and knowledge, respectively.

The answers of the knowledge part were scored:

Incorrect response $=0$

Adequate response $=1$

Ideal response $=2$. The final scores then categorized into two categories; inadequate knowledge and adequate knowledge.

The attitude section was composed of 8 questions, with five possible answers for each one (strongly agree, agree, uncertain, disagree, and strongly disagree). So the total scores in the section ranged from 8 to 40 , then the final scores categorized into three ; negative, fair and positive attitude.

\section{Data analysis}

The data had been cleaned, coded, entered into the computer program, and analyzed using statistic package for social sciences (SPSS) version 17. Demographic data, self assessment data, knowledge of tooth fracture, and attitude were first analyzed using descriptive statistics. T-test, ANOVA, plus Pearson correlation coefficients used to determine the relationship between the different variables.

\section{Ethical considerations}

Ethical approval and written permission to conduct the study was obtained from the research committee, University of Khartoum, Faculty of Dentistry, Ministry of Health and Ministry of Education authorities in Khartoum state. In addition to verbal informed consent from the participants.

\section{Results}

The total number of school teacher participated in this study was 207 , filled and returned the questionnaire, 12 of them were excluded due to incomplete answers. Accordingly the response rate of was the survey $94 \%$.

\section{Socio-demographic characteristics}

Among the participants, $71.3 \%$ were females and $28.7 \%$ were males. Sixty six percent of the participants aged $35-45$ years. The educational levels; $3.1 \%$ high school, $10.8 \%$ diploma, $76.9 \%$ bachelor and $9.2 \% \mathrm{MSc}$. Only $15.4 \%$ had previous educational lectures in oral health in general. Majority of the participants (85.6\%) had witnessed some sort of dental trauma.

In this study, one-way analysis of variance and t-tests did not show any statistically significant difference between knowledge and demographic variations $(P>0.05)$. Table 1 showed the frequency of answers to part I questionnaire.

\section{Self-assessment section}

Most teachers (90.3\%) were unsatisfied with their level of knowledge, $67.7 \%$ can provide the proper action when needed, $96.9 \%$ wanted further education on the topic, and 57.7 of them want it to be as a part of their regular training as school health teachers. (Table 2).

\section{Knowledge section}

\section{Case I: Crown fracture}

Less than half of the teacher 84 (43.0\%) knew that the damaged tooth was permanent. As an immediate action, $26.2 \%$ of them said that they would re-assure the child and return him to class. Of all respondents, $53.4 \%$ said that they would contact the child's parents to get him/her to a dentist. Only $17.4 \%$ answered that they would keep the fractured piece, while $4.6 \%$ did not know what to do. The general knowledge regarding tooth fracture is grossly lacking, just $35.4 \%$ of the teachers had adequate knowledge (Figures 1,2 and 3).

Case II: Permanent tooth avulsion

Table 3 showed the responses to questions regarding tooth avulsion. No more than $5.1 \%$ selected the response 'find the tooth, wash it, and put it back in its place in the mouth', While $35.4 \%$ saved the tooth and seek a professional help. Unfortunately, the majority responded incorrectly by stopping the oral bleeding and sends the child home or don't know what to do. Considering how would they hold the tooth, just $8 \%$ of the respondents selected the correct answer figure 4 .

In table 4 answer about how would they clean the tooth after dental avulsion when it has fallen out, almost $24.7 \%$ responded correctly

Table 1. Socio- demographic characteristics of teachers.

\begin{tabular}{|l|c|c|}
\hline Characteristic & Frequency & Percent \\
\hline Gender & 139 & $71.3 \%$ \\
Female & 56 & $28.7 \%$ \\
\hline Male & & \\
\hline Age & 39 & $20.0 \%$ \\
$<35$ years & 129 & $66.2 \%$ \\
$36-45$ years & 27 & $13.8 \%$ \\
\hline$>45$ years & & \\
\hline Education & 6 & $3.1 \%$ \\
High school & 21 & $10.8 \%$ \\
Diploma & 150 & $76.9 \%$ \\
Bachelor & 18 & $9.2 \%$ \\
\hline MSc & & \\
\hline Received training for dental emergency & 27 & $13.8 \%$ \\
\hline Yes & 168 & $86.2 \%$ \\
\hline No & & \\
\hline Witnessed dental trauma before & 167 & $85.6 \%$ \\
\hline Yes & 28 & $14.4 \%$ \\
\hline No & & \\
\hline
\end{tabular}

Table 2. Distribution of the teachers according to self-assessment answers.

\begin{tabular}{|l|c|c|c|c|c|c|}
\hline \multirow{2}{*}{ Questions } & \multicolumn{2}{|c|}{ Frequency } & \multicolumn{2}{|c|}{ Percent } & Mean & $\begin{array}{c}\text { Std. } \\
\text { Deviation }\end{array}$ \\
\cline { 2 - 5 } & Yes & No & Yes & No & & .297 \\
\hline $\begin{array}{l}\text { Is your knowledge on dental } \\
\text { emergency management enough? }\end{array}$ & 19 & 176 & $9.7 \%$ & $90.3 \%$ & 1.90 & .297 \\
\hline $\begin{array}{l}\text { Are you able to provide proper action } \\
\text { when needed? }\end{array}$ & 132 & 63 & $67.7 \%$ & $32.3 \%$ & 1.31 & .462 \\
\hline $\begin{array}{l}\text { Do you need future education in this } \\
\text { regard? }\end{array}$ & 189 & 6 & $96.9 \%$ & $3.1 \%$ & 1.03 & 183 \\
\hline
\end{tabular}




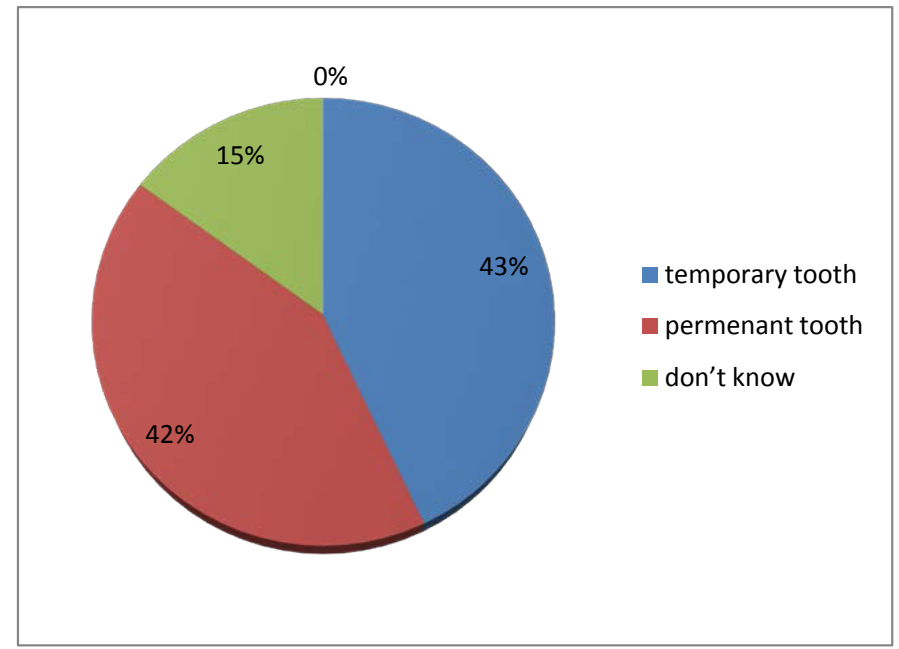

Figure 1. Distribution of the teacher according to the knowledge of tooth fracture.

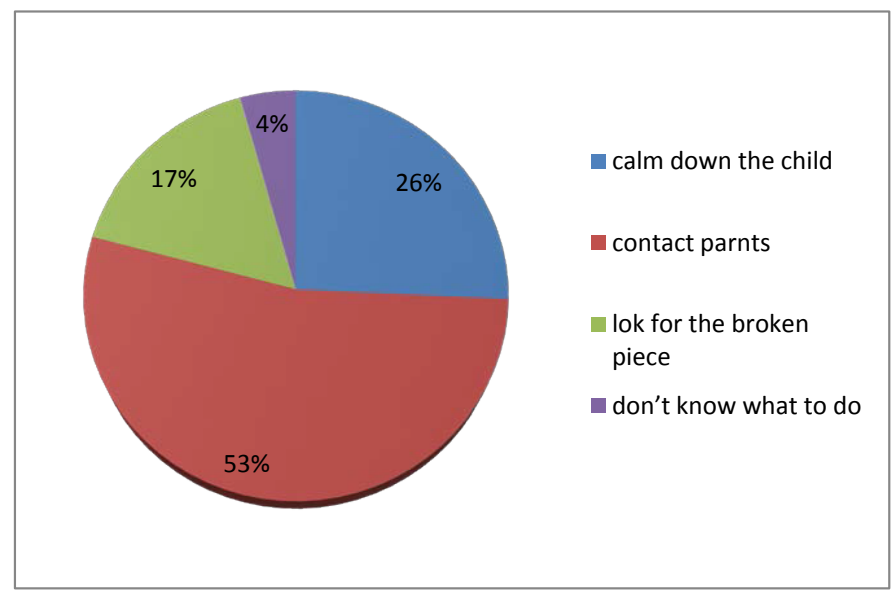

Figure 2. Distribution of the teacher according to the knowledge of tooth fracture emergency management.

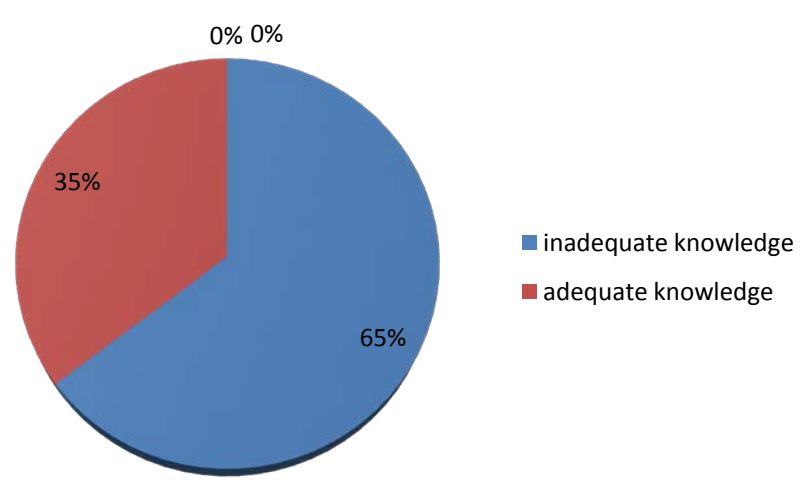

Figure 3. Distribution of the teacher according to the knowledge evaluation in regard to management of tooth fracture.

by washing the tooth under the tap water, while $19.5 \%$ stated that they would use sponge and soap to rub the dirt out. Unfortunately the majority $(36.8 \%)$ stated that they would discard the tooth. The results for the question 'If you didn't replant the tooth, how would you transport it to the dentist?', only $12.6 \%$ and $2.3 \%$ selected saline solution and fresh milk, respectively, as the storage medium, while $49.1 \%$ suggested that they would carry it in a handkerchief or tissue paper, the remaining subjects responded as follow; tap water $(5.7 \%)$, disinfectant solution (33.1\%), ice (4.0\%) table 5 .

In general when the teacher evaluated about the knowledge concerning traumatic dental injury it recorded that almost all of them (97\%) had in adeque knowledge concerning tooth avulsion figure 5.

\section{Attitude section}

Table 6 summarizes the responses to attitude questions. About $78.2 \%$ of the respondents remarked that teachers are responsible for the provision of emergency care to the dental trauma suffered by the pupils at schools. Regarding the effect of time on long-term prognosis, $89.1 \%$ believed that the time is an important effective factor. Ninety two percent believed that first-aid training, including dental emergency management, must be one of the priorities in teachers' educational programs. And $92 \%$ of the respondents were aware of the important role of the teacher in improving the prognosis.

In this study, the mean score for attitude was 32.0 with a standard

Table 3. Distribution of the teacher according to the knowledge of emergency management of tooth avulsion.

\begin{tabular}{|l|c|c|c|c|}
\hline \multicolumn{1}{|c|}{ Answers } & $\begin{array}{c}\text { Frequency } \\
\text { (yes) }\end{array}$ & $\begin{array}{c}\text { Valid } \\
\text { percent }\end{array}$ & Mean & Std. Deviation \\
\hline $\begin{array}{l}\text { Stop the bleeding and send the } \\
\text { child home }\end{array}$ & 113 & 57.9 & 1.39 & .488 \\
\hline $\begin{array}{l}\text { Look for the tooth, wash it and } \\
\text { put it back in its place. }\end{array}$ & 10 & 5.1 & 1.95 & .222 \\
\hline $\begin{array}{l}\text { Save the tooth and look for } \\
\text { professional help. }\end{array}$ & 69 & 35.4 & 1.68 & .468 \\
\hline Don't know what to do. & 13 & 6.7 & 1.93 & .264 \\
\hline
\end{tabular}

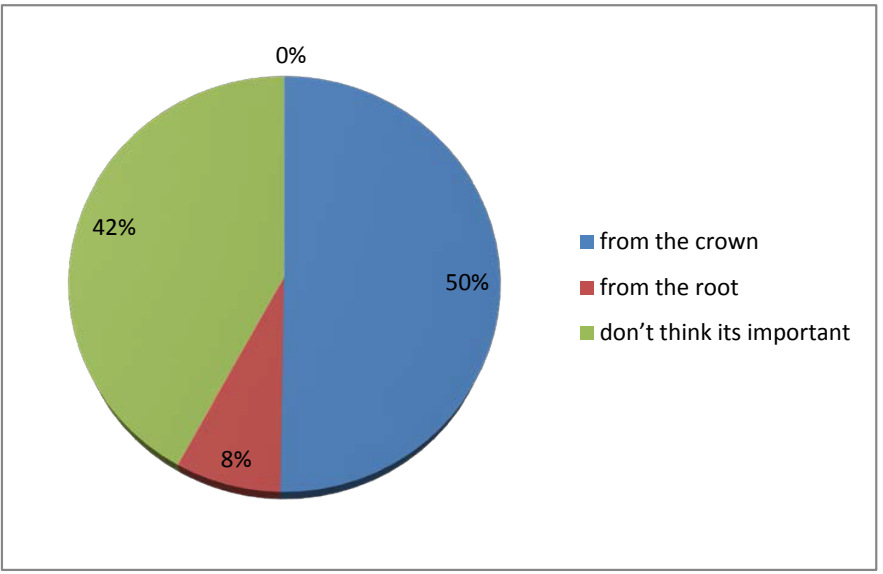

Figure 4. Distribution of the methods how to hold the avulsed tooth.

Table 4. Distribution of the teacher according to their knowledge of How to clean the avulsed tooth.

\begin{tabular}{|c|c|c|c|c|}
\hline Answers & $\begin{array}{c}\text { Frequency } \\
\text { (yes) }\end{array}$ & $\begin{array}{c}\text { Valid } \\
\text { percent }\end{array}$ & Mean & Std. Deviation \\
\hline Rinse the tooth under tap water & 43 & $24.7 \%$ & 1.75 & .433 \\
\hline $\begin{array}{l}\text { Rub away the dirt by a sponge } \\
\text { and soap. }\end{array}$ & 34 & $19.5 \%$ & 1.80 & .398 \\
\hline $\begin{array}{l}\text { Put it back into the socket } \\
\text { immediately without cleaning. }\end{array}$ & 0 & $0 \%$ & 2.00 & .000 \\
\hline Discard the tooth. & 64 & $36.8 \%$ & 1.63 & .484 \\
\hline Don't know what to do. & 34 & $19.5 \%$ & 1.80 & .398 \\
\hline
\end{tabular}


Table 5. Distribution of the teacher according to their selection of storage medium.

\begin{tabular}{|l|c|c|c|c|}
\hline \multicolumn{1}{|c|}{ Answers } & $\begin{array}{c}\text { Frequency } \\
\text { (yes) }\end{array}$ & $\begin{array}{c}\text { Valid } \\
\text { percent }\end{array}$ & Mean & Std. Deviation \\
\hline Put the tooth in ice & 7 & 4.0 & 1.90 & .304 \\
\hline Put the tooth in Saline solution & 22 & 12.6 & 1.73 & .448 \\
\hline $\begin{array}{l}\text { put the tooth in a disinfectant } \\
\text { solution }\end{array}$ & 58 & 33.1 & 1.44 & .499 \\
\hline put the tooth in Fresh milk & 4 & 2.3 & 1.94 & .235 \\
\hline put the tooth in Tap water & 10 & 5.7 & 1.86 & .348 \\
\hline $\begin{array}{l}\text { Wrap the tooth in a handkerchief } \\
\text { or paper tissue }\end{array}$ & 86 & 49.1 & 1.26 & .440 \\
\hline
\end{tabular}

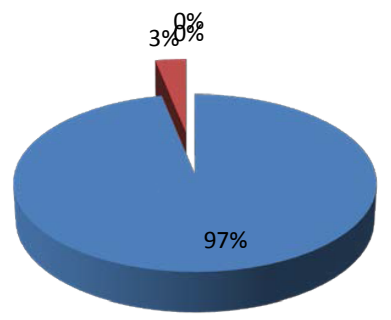

— inadequate knowledge

adequate knowledge

Figure 5. Distribution of the teacher according to the knowledge regard tooth avulsion management.

Table 6. Frequency of the teacher answers regarding the attitude evaluation with regard to dental trauma management.

\begin{tabular}{|c|c|c|c|c|c|c|c|c|c|c|}
\hline \multirow[t]{2}{*}{ Question } & \multicolumn{2}{|c|}{ Strongly agree } & \multicolumn{2}{|c|}{ Agree } & \multicolumn{2}{|c|}{ Uncertain } & \multicolumn{2}{|c|}{ Disagree } & \multicolumn{2}{|c|}{ Strongly disagree } \\
\hline & $\mathbf{N}$ & $\%$ & $\mathbf{N}$ & $\%$ & $\mathbf{N}$ & $\%$ & $\mathbf{N}$ & $\%$ & $\mathbf{N}$ & \\
\hline Q1 & 6 & 3.1 & 26 & 13.4 & 10 & 5.2 & 100 & 51.5 & 52 & 26.8 \\
\hline Q2 & 71 & 36.8 & 105 & 54.4 & 11 & 5.7 & 2 & 1.0 & 4 & 2.1 \\
\hline Q3 & 2 & 1.0 & 22 & 11.4 & 28 & 14.5 & 75 & 38.9 & 66 & 34.2 \\
\hline Q4 & 63 & 32.6 & 115 & 59.6 & 4 & 2.1 & 8 & 4.1 & 3 & 1.6 \\
\hline Q5 & 6 & 3.1 & 28 & 14.7 & 13 & 16.8 & 88 & 46.1 & 56 & 29.3 \\
\hline Q6 & 69 & 35.6 & 110 & 56.7 & 8 & 4.1 & 3 & 1.5 & 4 & 2.1 \\
\hline Q7 & 15 & 7.7 & 30 & 15.4 & 11 & 5.6 & 96 & 49.2 & 43 & 22.1 \\
\hline Q8 & 70 & 36.1 & 108 & 55.7 & 7 & 3.6 & 8 & 4.1 & 1 & 0.5 \\
\hline
\end{tabular}

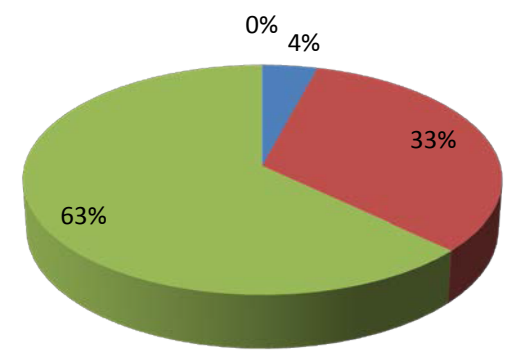

negative attitude

- fair attitude

positive attitude

Figure 6. Distribution of the teacher according to general attitude evaluation with regard to dental trauma management. deviation of 4.01. One-way analysis of variance and t-tests were used to test differences in the score of the study participants' attitude across demographic characteristics and work experiences. A significant difference ( $p<0.001)$ was observed only between having participated in first-aid programs and attitude scores (teachers who were trained in first aid, presented a more positive attitude).

\section{Discussion}

According to the results of the present study, $84.6 \%$ of teachers did not receive any training for dental emergencies. This finding was in consistent with previouspublished studies[9,11].

It is worth noting that $86.8 \%$ of teachers in the current study witnessed a dental trauma, which in contrast to the results reported by McIntyre in USA where $69 \%$ of the respondents never witnessed a TDI[10], however it in agreement with the results in Tanzanian sample[13]. This finding reinforces the need for teachers to be well informed in dental emergency management.

No statistically significant difference were found in the present study between the knowledge level of teacher who had formal first-aid training and those who did not, which in a line with the findings in Singapore and Jordan results $[9,14]$.

The current results revealed that $96.6 \%$ of the teachers were keen to receive more information on dental injuries, which in agreement with previous results in literature among different population $[9,11,15,16]$.

In case I, a rather distressing finding in our study was the fact that $61.1 \%$ did not know the fractured tooth would be permanent in a 9 -year-old student. Knowledge in this area is grossly lacking and may lead to neglect in timely and proper management of a permanent tooth that affects the long-term prognosis. This finding was in contrast with the study in Hong Kong, where more than $70 \%$ of the respondents were knowledgeable in this field [15].

The present study showed that only $18.5 \%$ responded that they would search for pieces of the fractured tooth, the finding as the same to that found in Jordan[9]. Similarly, Vergotine and Govoni reported that a low number of teachers knew that a dentist could re-attach a tooth fragment [17].

The time lapse after avulsion and the storage media are two of the most important factors preserving the periodontal ligament (PDL) cells and improving the prognosis for an avulsed tooth[18,19].

In case II, only $5.1 \%$ of our respondents stated they would immediately replant an avulsed tooth. The majority were concerned with stopping the bleeding which could be related to the fact that bleeding is life-threatening for children. Similar results were observed in the studies by Chan and Mohandas $[15,20]$. Whereas in a study conducted in Iran, one in five was aware with appropriate time limits for replantation [21].

Approximately one-third of the participants said that they do not make any effort to replant or preserve a tooth when it had fallen out on the ground and was covered in dirt. This result in consistent with the study carried out by Caglar[22], but the figure was much higher when compared with that obtained in the Al-Asfouret al.[23].which indicates inadequate knowledge and the need for in-service dental emergency training for school teachers.

Only $2.3 \%$ of Sudanese teacher chose milk as a proper storage medium, similar to results $4 \%$ obtained in Tanzania[13], $10 \%$ in Turkey[24], and 9\% in Hong Kong[15].In contrast the current 
response was lower than the responses obtained in the studies carried by Blakytny, McIntyre, and Vergotine[10,17,25].Which designate that our participantshad less knowledgeable regarding correct transport and storage media.

Most of the teacher in this study felt they should be responsible for the management of dental traumatic injuries in school and believed that they could improve the prognosis by early and correct intervention. More than $90 \%$ of the participants suggested that management of traumatized teeth to be a priority for their health educational programs.

Overall, the results showed that the Sudanese teacher had a positive attitude toward managing traumatic dental injuries, although their knowledge was deficient. On the other handstudy for Sudanese primary school teachers had been carried out by Malaz N. and Amal H. regarding Knowledge and attitude for emergency management of dental trauma, and the results revealed that the majority of the teachers neither receive first aid training $62 \%$ nor dental emergency management $67.4 \%$ and recommended first aid and dental trauma management training should be compulsory for all primary school teachers in Sudan[26].

\section{Conclusion}

- Based on the result of this study, the general knowledge of the Sudanese school health teachers was inadequate.

- $\quad$ Ninety percent of the participants were unsatisfied with their knowledge of emergency management of TDIs.

- The attitude of the participants in general was positive.

\section{Recommendations}

- Dental emergency education program should be a part of the annual health educational course carried out by Khartoum school management health for school health teachers, to improve the knowledge and awareness of this group of society.

- Economically efficient methods of intervention, like Educational posters or Pamphlet should be considered.

- Further research is needed to determine the most effective method to improve the knowledge of school health teachers.

\section{References}

1. Glendor U (2008) Epidemiology of traumatic dental injuries - a 12 year review of the literature. Dent Traumatol 24: 603-611. [Crossref]

2. Andreasen JO, Andreasen FM, Andersson L (2007) Textbook and Color Atlas of Traumatic Injuries to the Teeth. (4th edn.) Wiley-Blackwell: 912.

3. Traebert J, Lacerda JT, Foster Page LA, Thomson WM, Bortoluzzi MC (2012) Impact of traumatic dental injuries on the quality of life of schoolchildren. Dent Traumatol 28: 423-28. [Crossref]

4. Thelen DS, Trovik TA, Bårdsen A (2011) Impact of traumatic dental injuries with unmet treatment need on daily life among Albanian adolescents: a case-control study. Dent Traumatol 27: 88-94. [Crossref]

5. Aldrigui JM, Abanto J, Carvalho TS, Mendes FM, Wanderley MT (2011) Impact of traumatic dental injuries and malocclusions on quality of life of young children. Health Qual Life Outcomes 9: 78-85. [Crossref]

6. Andreasen JO (1985) Challenges in clinical dental traumatology. Endod Dent Traumatol 1: 45-55. [Crossref]

7. Baghdady VS, Ghose LJ, Enke H (1981) Traumatized anterior teeth in Iraqi and Sudanese children--a comparative study. J Dent Res 60: 677-680. [Crossref]

8. Abuaffan AH, Elsideeg SE (2015) Traumatic dental injuriesand associaed risk factoe among Sudanese sch amonge school children. J Dent Oral Care 1: 1-4.

9. Al-Jundi SH, H. Al-Waeili, Khairalah K (2005) Knowledge and attitude of Jordanian school health teachers with regards to emergency management of dental trauma. Dent Traumatol 21:183-187. [Crossref]

10. McIntyre JD, Lee JY, Trope M, Vann WF Jr. (2008) Elementary school staff knowledge about dental injuries. Dent Traumatol 24: 289-298. [Crossref]

11. Raoof M, Zaherara F, Shokouhinejad N, Mohammadalizadeh S (2012) Elementary school staff knowledge and attitude with regard to first-aid management of dental trauma in Iran: a basic premise for developing future intervention. Dent Traumatol 28: 441-447. [Crossref]

12. Cronbach LJ (1951) Coefficient alpha and the internal structure of tests. Psychometrika 16: 297-334.

13. Kahabuka FK, Van't Hof M, Willemsen W, Burgersdijk R (2003) Influence of seminar and mailed guidelines on knowledge of school teachers regarding emergency treatment for dental injuries. East Afr Med J 80:105-109. [Crossref]

14. Sae-Lim V, Lim LP (2001) Dental trauma management awareness of Singapore preschool teachers. Dent Traumatol 17: 71-76. [Crossref]

15. Chan AW, Wong TK, Cheung GS (2001) Lay knowledge of physical education teachers about the emergency management of dental trauma in Hong Kong. Dent Traumatol 17: 77-85. [Crossref]

16. Al-Obaida M (2010) Knowledge and management of traumatic dental injuries in a group of Saudi primary schools teachers. Dent Traumatol 26: 338-341. [Crossref]

17. Vergotine RJ, Govoni R (2010) Public school educator's knowledge of initial management of dental trauma. Dent Traumatol 26: 133-136. [Crossref]

18. Andreasen JO, Andreasen FM, Skeie A, Hjørting-Hansen E, Schwartz O (2002) Effect of treatment delay upon pulp and periodontal healing of traumatic dental injuries. Dent Traumatol 18:116-128. [Crossref]

19. Barrett EJ, Kenny DJ (1997) Avulsed permanent teeth: a review of the literature and treatment guidelines. Endod Dent Traumatol 13:153-163. [Crossref]

20. Mohandas U, Chandan GD (2009) Knowledge, attitude and practice in emergency management of dental injury among physical education teachers: a survey in Bangalore urban schools. J Indian Soc Pedod Prev Dent 27: 242-248. [Crossref]

21. Mesgarzadeh AH, Shahamfar M, Hefzollesan A (2009) Evaluating knowledge and attitudes of elementary school teachers on emergency management of traumatic dental injuries: a study in an Iranian urban area. Oral Health Prev Dent 7: 297-308. [Crossref]

22. Caglar E, Ferreira LP, Kargul B (2005) Dental trauma management knowledge among a group of teachers in two south European cities. Dent Traumatol 21: 258-262. [Crossref]

23. Al-Asfour A, Andersson L, Al-Jame Q (2008) School teachers' knowledge of tooth avulsion and dental first aid before and after receiving information about avulsed teeth and replantation. Dent Traumatol 24: 43-49. [Crossref]

24. Arikan V, Sonmez H (2012) Knowledge level of primary school teachers regarding traumatic dental injuries and their emergency management before and after receiving an informative leaflet. Dent Traumatol 28: 101-107. [Crossref]

25. Blakytny C, Surbuts C, Thomas A, Hunter ML (2001) Avulsed permanent incisors: knowledge and attitudes of primary school teachers with regard to emergency management. Int J Paediatr Dent 11: 327-332. [Crossref]

26. Siddig MN, Abuaffan AH (2015) Knowledge and attitude of primary school teacher regarding emergency management of dental trauma, in Khartoum. Ind J Edu 8: 13-121.

Copyright: (C2016 Mergany NN. This is an open-access article distributed under the terms of the Creative Commons Attribution License, which permits unrestricted use, distribution, and reproduction in any medium, provided the original author and source are credited. 